\title{
Job Satisfaction of Library Staff: A Study Based on University Libraries in Sri Lanka
}

\author{
R.A.A.S. Ranaweera (Corresponding Author) \\ ${ }^{1}$ PhD Student, School of Information Management, Wuhan University, Wuhan, P.R. \\ China, 430072 \\ ${ }^{2}$ Senior Assistant Librarian, Library, University of Kelaniya, Dalugama, Sri Lanka
}

Prof. Si Li

Professor, The Center for the Study of Information Resources, Wuhan University, Wuhan, P.R. China, 430072

D. Bodhinayaka

Assistant Librarian, Library, University of Kelaniya, Dalugama, Sri Lanka

Received: May 10, 2018 Accepted: May 23, 2018 Online published: May 24, 2018

doi:10.5296/ijhrs.v8i3.13190 URL: https://doi.org/10.5296/ijhrs.v8i3.13190

\begin{abstract}
Library of a university considered as an important entity of a university and employees of the library have a key role to play in disseminating knowledge to the academic clientele in the university. This study conducted to comprehensively investigate the job satisfaction of employees as the main objective and followed by identifying the main factors and finally to provide suggestions to overcome the dissatisfaction level of jobs of staff serving in respective universities. Study sample comprised with 510 respondents representing all professional, para-professional and support staff categories working in 14 university libraries in Sri Lanka. Semi structured questionnaire with five point likert scale used to collect quantitative data for the study. The study findings indicates that university library employees were moderately satisfied with their jobs and in general and co-workers, salary and benefits, physical working condition, career development opportunities, work itself, appreciation and feedback identified as the main factors of job satisfaction. The present study recommend to take immediate measurements to enhance the level of job satisfaction among employees by enhancing a collaborative working atmosphere, provide more career development opportunities, establish
\end{abstract}


a proper mechanism for provide appreciation and feedback to enrich the current level of job satisfaction of library staff.

Keywords: Job Satisfaction, University Library, Sri Lanka, Library Professionals, Para-professional Staff

\section{Introduction}

Satisfaction about the inherent characteristics of their job status of employees is very important to any organization for the success and future existence. Also it is a key component for enhancing the productivity of the organization and as well as the career development and success of the employees (Kaba, 2017). Employees spend an extensive period of time at the working place, it is important to discover the opinion of individuals on their job and its inherent status. Theoretically, the topic of job satisfaction as considered as one of the widely and frequently researched topic in the organization behavior studies due to its inherent nature (Memon \& Jena, 2017). As cited by Hussain and Soroya (2017), it was Happack, in 1935, for the first time identified the concept and the phenomenon of job satisfaction as a combination of psychological, physiological and external circumstances which lead a person to state that he or she is satisfied with his or her job. Although different researchers have been defined the concept of employee 'job satisfaction' in different ways, it is simply recognized as a perception of employees towards on their own job and correlated aspects and how they are measure their job in between satisfy to dissatisfy. Herzberg and Maslow, two eminent scientists who studied about the motivation factor of jobs, recognized needs, attitudes and attributes or feelings as three theoretical frameworks to be fulfilled in satisfaction. Herzberg in 1857 developed the theory of motivation and hygiene to understand about the feelings of workers and concluded that they would be satisfied when their basic necessities were fulfilled in a good manner. Additionally, job satisfaction is a complex scenario in nature and it is associated with a number of fundamental elements (Okaro, Eze \& Ohagwu, 2010).

Universities have been established as higher educational institutions or centers for sharing knowledge, conducting innovative researches, and engaging in the community development activities (Adio \& Popoola, 2010). In this circumstance, academic library plays a key role as a core unit of a university and considers as a centre of an academic life. The support given by the library staff members is very important for the smooth process of the system. Professional and other staff is a key resource and significant component in any library and each and every staff member has a specific and dynamic role and a responsibility to pay in achieving the main objectives of particular library. Delivering an effective and productive library and information service to the patrons is completely depend on the library staff and such a service is easy to render when the library staff is satisfied with their jobs (Tinuoye, Omeluzor \& Akpojotor, 2010). This present scenario has created a very good stage to researchers to conduct studies on evaluation on satisfaction levels on jobs of staff members serving in university libraries.

\section{Literature Review}

It has been noticed that a number of attempts have been taken to study and assess about the job satisfaction levels of workers attached to university libraries all over the world. Peng 
(2014), tried to co-relate level of workers' performance with their satisfaction levels by taking 735 numbers of librarians in eighty universities in Taiwan province, China. He used to analyze the job satisfaction scenario using the Structural Equation Modeling (SEM). In this case study, he used intrinsic as well as extrinsic factors to create the model. Results showed that facets of intrinsic job satisfaction have strong influence on job performance. Khan, Masrek and Nadzar (2017) analyzed the problem in a different approach taking emotional intelligence as the key factor. This study was done among academic librarians in Pakistan. The survey has been found self assessment as the first predictor and optimism as the last predictor of job satisfaction. Since this concept has been opened a new study area under satisfaction of jobs, recommendations and suggestions of this study can be used to improve the librarians' works which eventually would lead to maintain an effective service and better customer service in the users' point of view.

In Sri Lanka, few studies have been carried to explore the job satisfaction of university library staff and all those studies were limited in scope and mainly focused on professional staff only. The first attempt to discuss about job satisfaction of university library staff was in 1994 and limited to fifty professionals in ten universities (Thirunavukarasu, 1994). Wijeweera (2004) studied about the scenario of agricultural based libraries using fifteen variables. He further found out that female employees are more attracted to their career than male counterparts. As per the results, age group of most satisfied group was 30-34 years. It further shows that there is a gradual drop about their satisfaction rate with the age. This study recommended to implement a good scheme for promotions, career development, and foreign trainings which satisfies the workers gently. Marasinghe and Wijeratne (2016) evaluated the problem in a different approach in which three generations: Baby Boomers, Generation X and Generation Y by using work, co-workers, compensations, supervision and promotions as parameters in the study. Study results identified that job satisfaction changes with the generation. In the case of parameters such as 'work' and 'supervision', baby boomers were much satisfied their work than the others. Generation $\mathrm{Y}$ had shown a higher level of satisfaction than others. Several guidelines had been suggested by them in order to satisfy professionals in university libraries in Sri Lanka.

\section{Objectives}

There is a research gap in the local library science literature to comprehensively explore the level of job satisfaction of all three job categories; professional, para-professional and support staff serving in universities. Therefore, the present study carried to comprehensively investigate the level of job satisfaction of staff members in university libraries in Sri Lanka and followed by identifying the main factors related to job satisfaction of employees, explore the factors related to their job dissatisfaction and finally to provide suggestions to overcome the dissatisfaction level of jobs in staff serving in respective university libraries.

\section{Methodology}

This study planned to cover entire university library staff population. However, due to the delay of getting permission for data collection, one university had to drop from the population. Finally, out of fifteen national university libraries with the population of 707 
members, 643 employees selected as the study sample for this study from fourteen universities across the country. Out of 643 respondents, 525 sent their filled questionnaires and finally $510(79.32 \%)$ usable duly filled questionnaires were taken into the final data analysis. This study utilized mixed method research design and survey questionnaire used to obtained data. Survey questionnaire was designed in four parts to obtained demographic information on respondents, factors related to job satisfaction and staff perception on their level of job satisfaction. 5 point Likert scale ranging from 1-5 (Strongly Disagree, Disagree, Neither agree nor disagree, Agree and Strongly agree) was used as the type of score in the questionnaire. Collected data were mainly analyzed with frequency and descriptive statistically analyzing techniques in the Statistical Package for Social Science (SPSS) version 22 for windows.

\section{Results and Discussion}

\subsection{Reliability Analysis of the Questionnaire}

Reliability of the questionnaire was tested by using cronbach's alpha test and alpha values indicates 0.673 for the overall job satisfaction ( 4 items) and 0.882 for the factors of job satisfaction (27 items) as shown in Table 1. These values, further, verify that the survey questionnaire is in the reliable and suitable format.

Table 1. Summery of the Cronbach's alpha analysis

\begin{tabular}{c|c|c}
\hline Dimension & $\begin{array}{l}\text { Number of } \\
\text { Items }\end{array}$ & $\begin{array}{c}\text { Cronbach's } \\
\text { Alpha }\end{array}$ \\
\hline Overall job satisfaction & 04 & .673 \\
\hline Job satisfaction factors & 27 & .882 \\
\hline
\end{tabular}

$\mathrm{N}=510$, Significance level of $<.001$

\subsection{Demographic Profile of the Sample}

Gender distribution of the sample consisted with $50.8 \%$ males and $49.2 \%$ of the female and there was not much significant differences showed with regard to gender of the sample. $31.2 \%$ represented the age group between 41-50 years and 20-30 of age group represented a $16.7 \%$ of the sample. An extensive percentage $(47.7 \%)$ of staff members were having working experience of between 11-30 years and $45 \%$ were experience of their work in the university library less than 10 years.

\subsection{Level of Job Satisfaction of Employees}

The first research objective of this study was to explore the level of job satisfaction of employees. Table 2 indicated the survey results regarding the level of job satisfaction of university library staff. Based on the survey result, respondents were indicates mean value of 3.62 for the question 'if a good friend of mine was interested in working in my job, I would encourage him to take it'. Also, with a highest mean value of 3.93, respondents were denoted that 'if they had to start their professional career life again, they would definitely take the current job'. Overall mean value 3.74 signify that the university library employees in Sri Lanka were moderately satisfied with their jobs in libraries. 
Table 2. Level of job satisfaction of employees

\begin{tabular}{l|l|l}
\hline \multicolumn{1}{c|}{ Variables } & Mean & $\begin{array}{c}\text { Std. } \\
\text { Deviation }\end{array}$ \\
\hline $\begin{array}{l}\text { If a good friend of mine was interested in working in my job, I would encourage } \\
\text { him to take it }\end{array}$ & 3.61 & 1.064 \\
\hline Job satisfaction motivates me to do my job well & 3.69 & .954 \\
\hline If I had to start my career again, I would take my current job & 3.92 & .867 \\
\hline In general, I am satisfied with my job & 3.7 & .884 \\
\hline Overall Job satisfaction & 3.74 & .922 \\
\hline
\end{tabular}

\subsection{Factors of Job Satisfaction}

As per the Table 3, the highest mean value which is 3.81 was recorded for the item ' $I$ find my work is interesting'. The second highest mean value (3.71) recorded for the item 'I feel that my work place is a safe environment mean value of 3.71. Additionally, 'I Like people I work with' also received the relatively high mean value of 3.61 .

Table 3. Factors of job satisfaction

\begin{tabular}{|c|c|c|c|}
\hline Q.no. & Items & Mean & $\begin{array}{c}\text { Std. } \\
\text { Deviation }\end{array}$ \\
\hline 01 & $\begin{array}{l}\text { My Salary is appropriate in relation to the job duties } \\
\text { and responsibilities }\end{array}$ & 3.48 & 1.09 \\
\hline 02 & My Job is enjoyable & 3.23 & 1.14 \\
\hline 03 & I Like people I work with & 3.61 & .93 \\
\hline 04 & $\begin{array}{l}\text { Ventilation, furniture \& other hygiene facilities are available } \\
\text { to perform my duties in the library }\end{array}$ & 3.02 & 1.20 \\
\hline 05 & I am satisfied with the benefits that I receive at the University & 3.17 & 1.12 \\
\hline 06 & My subordinates are honest and obedient & 3.09 & 1.13 \\
\hline 07 & My department provides sufficient material for our use & 3.20 & 1.10 \\
\hline 08 & My salary is sufficient to satisfy enough of my basic needs & 3.10 & 1.19 \\
\hline 09 & My job is challenging & 3.41 & 1.11 \\
\hline 10 & I am satisfied with my chances for promotion & 3.26 & 1.14 \\
\hline 11 & I enjoy my co-workers & 3.52 & .99 \\
\hline 12 & I am satisfied with my basic salary & 3.19 & 1.16 \\
\hline 13 & My job gives me opportunity to use my skills and abilities & 3.30 & 1.10 \\
\hline 14 & My co-workers and I work as a part of a team & 3.53 & .98 \\
\hline 15 & The physical environment allows me to do my job & 3.36 & 1.10 \\
\hline 16 & I feel that the work I do is appreciated & 3.16 & 1.11 \\
\hline 17 & $\begin{array}{l}\text { There is generally corporative and collaborative atmosphere } \\
\text { in the library }\end{array}$ & 3.24 & 1.06 \\
\hline 18 & I feel satisfied with my chances for salary increment & 3.27 & 1.06 \\
\hline 19 & I find my work interesting & 3.81 & .87 \\
\hline 20 & People care about each other in my library & 3.47 & 1.01 \\
\hline 21 & I have necessary resources, tools or equipment to do my job & 3.27 & 1.12 \\
\hline 22 & $\begin{array}{l}\text { Library provides me adequate feedback to the team on } \\
\text { its performance }\end{array}$ & 3.36 & 1.02 \\
\hline 23 & $\begin{array}{l}\text { My salary is equitable to the job that I do with compared } \\
\text { to other job categories in library field }\end{array}$ & 3.23 & 1.12 \\
\hline 24 & I feel that my work place is a safe environment & 3.71 & 2.02 \\
\hline 25 & $\begin{array}{l}\text { Benefits of my university are equal with the external } \\
\text { labour market }\end{array}$ & 2.84 & 1.08 \\
\hline 26 & It is easy to work with my colleagues & 3.43 & 1.00 \\
\hline 27 & $\begin{array}{l}\text { My library offers training or education that I need to grow } \\
\text { in my job }\end{array}$ & 3.01 & 1.14 \\
\hline
\end{tabular}

Conversely, some items in the table showed low mean values specially the items such as 'Ventilation, furniture \& other hygiene facilities are available to perform my duties in the library' (mean=3.02)', 'My library offers training or education that I need to grow in my job 
(mean=3.01) and 'benefits of my university are equal with the external labour market $($ mean $=2.84)$.

The 27 items depicted in Table 3, were categorized into seven main factors to identify the main factors related to context of job satisfaction of university library employees in Sri Lanka. Item no. 3,6,11,14 and 26 describe the factor of co-workers. Item numbers 1,5,8,12,18, 23 and 25 describe the salary and benefits. Physical working condition related items described under item numbers of 4,7,15,21 and 24 while 10,13 and 27 describe the factor of career development opportunities. Item number 2,9,19 describe work itself,16 and 22 describe appreciation and feedback and 17, 20 describe the factor of cooperation. Therefore, the present study identified that co-workers, salary and benefits, physical working condition, career development opportunities, work itself, appreciation and feedback and finally, cooperation as the factors related to context of employee job satisfaction of universities in Sri Lanka.

\section{Conclusion}

The present study carried out to seek answers for explore the level of job satisfaction, identify the main factors and finally to provide suggestions to improve the present level of job satisfaction of employees serving in university library system in Sri Lanka. Based on the survey findings, this study concluded that the employees were moderately satisfied with their jobs in university libraries in Sri Lanka. It is a positive indication that the staff members are not dissatisfied with their jobs. However, university authorities and library administrations must take precautions and measurements to enrich the present level of job satisfaction of employees to the fully satisfied level. The study further identified and lack of cooperation between workers, inadequate opportunities for career development and lack of proper mechanism for appreciation and feedback led staff dissatisfy with their jobs. Therefore, this study recommends to establish a collaborative working atmosphere within the library by organizing team building activities and job rotation programmes immediately. Also, university authorities and library administrators must provide facilities and opportunities to staff to attend programmes specially related to modern ICT developments. Finally, the immediate attention must be drawn to set up a proper method to provide feedback and evaluate the performance of employees to make them much satisfied and committed to their work in university libraries.

\section{References}

Adio, S., \& Popoola, O. (2010). Job satisfaction and career commitment of librarians in federal university libraries in Nigeria. Library Review, 59(3), 175-184. https://doi.org/10.1108/00242531011031160

Hussain, S., \& Soroya, S. H. (2017). Exploring the factors affecting job satisfaction of paraprofessional staff working in University Libraries of Pakistan. Library Review, 66(3), 144-162. https://doi.org/10.1108/LR-09-2016-0074

Kaba, A. (2017) Library employment: Satisfaction, Opportunities, and future actions as perceived by academic librarians. Library Management, 38(8/9), 511-527. https://doi.org/10.1108/LM-03-2017-0036

Khan, A., Masrek, M. N. F., \& Nadzar, M. (2017). Emotional intelligence and job satisfaction of academic librarians: An assessment of the relationship. Journal of Librarianship and Information Science, 49(2), 199-210. https://doi.org/10.1177/0961000616650733 


\section{Macrothink}

International Journal of Human Resource Studies

ISSN 2162-3058

2018, Vol. 8, No. 3

Marasinghe, L., \& Wijayaratne, A. (2016). A. Generational Differences and Job Satisfaction in University Library Professionals, Sri Lanka. Universal Journal of Management, 4(9), 500-507. https://doi.org/10.13189/ujm.2016.040904

Memon, N. Z., \& Jena, L. K. (2017).Gender Inequality, Job Satisfaction and Job Motivation: Evidence from Indian Female Employees. Management and Labour Studies, 42(3), 1-22. https://doi.org/10.1177/0258042X17718742

Okaro, O., Eze, C. U., \& Ohagwu, C. C. (2010). Survey of Job Satisfaction among Nigerian Radiographers in South-Eastern Nigeria. European Journal of Scientific Research, 39(3), 448-456.

Peng, Y. P. (2014). Job satisfaction and job performance of university librarians: A disaggregated examination. Library and Information Science Research, 36(1), 74-82. https://doi.org/10.1016/j.lisr.2013.02.006

Thirunavukarasu, K. (1994). Job Satisfaction among University Professional Librarians in Sri Lanka [Un published dissertation]. University of Colombo, 1994.

Tinuoye, O. O., Omeluzor, S. U., \& Akpojotor, L. O. (2016). Factors influencing job satisfaction of academic librarians in university libraries in Edo and Delta states, Nigeria.The Electronic Library, 34(6), 985-996. https://doi.org/10.1108/EL-07-2015-0128

Wijeweera, K. G. G. (2004). Job Satisfaction in Professionals and Paraprofessionals in Agriculture libraries in Sri Lanka. [Unpublished dissertation].University of Colombo.

\section{Copyright Disclaimer}

Copyright for this article is retained by the author(s), with first publication rights granted to the journal.

This is an open-access article distributed under the terms and conditions of the Creative Commons Attribution license (http://creativecommons.org/licenses/by/4.0/). 